\title{
REJUVENATING THE GROUNDWATER TAX STRATEGY IN GARUT REGENCY
}

Abstract: This research purpose to analyze the strategic and technical to encourage the potential of Regional Original Revenue (PAD) from the Groundwater Tax sector owned by Garut Regency. In this research used the descriptive method of research and qualitative approach to obtain the illustration of groundwater tax potential in Garut Regency. The primary and secondary data obtained by depth-interview technique to The Regional Revenue Office of Garut Regency. The data analysis using the formula on the growth, contribution and potential. Besides that, in this research use SWOT analysis to identify internal and external factors that influence the achievement of organizational goals based on strengths, weakness, opportunity, and threatness. The result of this research based on the growth measurement obtained the average of the ground water tax reached $-13.65 \%$ while the contribution of ground water tax to the regional tax was $0.83 \%$. Thus, to repair this condition based on the SWOT analysis the government of Garut Regency needs to conduct the intensification and extensification to increase groundwater tax revenues in Garut Regency as rejuvenating the policy of groundwater tax strategy in Garut Regency.

Abstrak: Penelitian ini bertujuan untuk menganalisis strategi dan teknis dalam mendorong potensi Pendapatan Asli Daerah (PAD) dari sektor Pajak Air Tanah yang dimiliki Kabupaten Garut. Dalam penelitian ini digunakan metode penelitian deskriptif dan pendekatan kualitatif untuk memperoleh gambaran potensi pajak airtanah di Kabupaten Garut. Data primer dan sekunder diperoleh dengan teknik wawancara mendalam kepada Dinas Pendapatan Daerah Kabupaten Garut. Analisis data menggunakan rumus pertumbuhan, kontribusi dan potensi. Selain itu dalam penelitian ini menggunakan analisis SWOT untuk mengidentifikasi faktor internal dan eksternal yang mempengaruhi pencapaian tujuan organisasi berdasarkan kekuatan, kelemahan, peluang, dan ancaman. Hasil penelitian berdasarkan pengukuran pertumbuhan diperoleh rata-rata pajak air tanah mencapai $-13,65 \%$ sedangkan kontribusi pajak air tanah terhadap pajak daerah sebesar $0,83 \%$. Oleh karena itu, untuk memperbaiki kondisi tersebut berdasarkan analisis SWOT maka Pemerintah Kabupaten Garut perlu melakukan intensifikasi dan ekstensifikasi untuk meningkatkan penerimaan pajak airtanah di Kabupaten Garut sebagai peremajaan kebijakan strategi pajak airtanah di Kabupaten Garut.

\author{
Muslim Al Kautsar ${ }^{1}$, Acep \\ Abdul Basit ${ }^{2}$, Abdullah \\ Ramdhani ${ }^{3}$, and Hanifah \\ Fauiziah $^{4}$ \\ 1,2,3,4 Universitas Garut, \\ Garut, Jawa Barat, Indonesia. \\ malkausar@uniga.ac.id
}




\section{Introduction}

The huge archipelago with thousands of islands illustrates the richness of Indonesia in natural resources. The abundant natural resources is scattered in various regions in Indonesia for instance in Garut Regency which are has a large of natural resources such as fertile land, water, various minerals, and other. Based on the several potential of each region and the lack of government to manage every natural resources owned to be preserved, as a result the government released the law of republic of Indonesia No. 33 of 2004 concerning Fiscal Balance Between Central Government and Regional Government to explain about regional autonomy that local governments regulate and manage their own government affairs, including in preserving nature in the region. As an autonomous region, the local government has a role in regulating economic activities to maintain the stability and welfare of its society (Mardiasmo, 2009). The regional government conducts infrastructure development for the period 2019-2024 is one of the development agendas that able to stimulate other developments such as housing development, shopping centers, tourist areas, rural developments, and etc. The repeatedly infrastructure development able to increase the community's necessity for ground water resources (Irianto \& Jurdi, 2005). In the fact, the contribution of local taxes on the Regional Budget Revenue and Expenditure in 2017 was only $2.20 \%$ lower than the average percentage of local tax contribution in all regencies/cities in Indonesia was $2.8 \%$. The one of local tax revenue obtain from groundwater taxes that indicate increased dramatically in 2015 of $104.082 \%$ of previous period, and gradually declined until ille 2017. This fact illustrates the lack of groundwater tax contribution on local tax income. This case indicates a problem in management of groundwater tax revenue. This decrease in tax revenue able to occur due to dry season until the surface water supply become less, or the lack of administrative ability of collection in regions because this taxation system using official assessment system.

Some facts that there has been a lot of corruption in the field of investment in various regions in Indonesia in various forms, including the arrest of the head of the Office of Investment and Integrated Services of the One Door of PL Regency, AH, extorted illegal levies on the issuance of a corporation's business license in the year 2018 (Akbar, 2018), a Japanese company, MC, has agreed to pay a fine of US \$ 85 million in the United States for bribing a number of officials and politicians in Indonesia (including the conviction of an EM person who received a bribe of US \$ 375 thousand) to win a power plant project Tarahan electricity in Lampung (Suparno, 2015), and the conviction of TFT, former Head of the Investment Coordinating Board (BKPM) in accordance with the decision of the District Court (PN) No. 07/PID.B/TPK/2006/PN.JKT.PST dated August 25, 2006, the decision of the Court of Appeal No. 16/PID/TPK/2006/PT.DKI dated October 20, 2006, and the Supreme Court (MA) cassation decision No. 103 K/PID/2007 dated 28 February 2007 because it enriched itself using the BKPM Indonesia Investment Year budget (KPK, 2020).

The importance of investment in improving the standard of living of the people, improving the country's economic growth, and increasing tax revenue, but the many regulations currently in force that show the supremacy of each regional authority and/or each institution's authority have created a great deal of potential legal confusion. incurs "unofficial" costs for investors. Meanwhile, the estuary of every illegal act that is motivated by the economy is very closely related to income and costs, wherein the case of the increasing number of illegal acts that are motivated by the economy, it will cause more unreported income especially if it comes from informal income from fraudulent practices (Abhimanyu, 2009) and more costs are not officially reported by certain entities that provide informal income. This background emerges as the main problem that will answer the research question: how to reorient taxes as a means of preventing corruption in 
the investment sector in Indonesia. What is water that is in the bowels of the earth, meant by reorientation is that the root comes including springs that appear naturally above from the word orientation, as according to ground level ". According to (Mardiasmo, the Big Indonesian Dictionary (KBBI, 2020) 2009), the object of ground water tax is online has the meaning as (1) review to divided into 2, namely groundwater determine the right (right, place, etc.) attitude extraction, and ground water utilization. The (direction, place, etc.); (2) views that Water Value Factors and Components (Fnunderlie thoughts, concerns or tendencies. Water) contain (1) groundwater natural While the affix "re" in the word resources determined by groundwater type "reorientation" has the meaning repeated or factors , location of ground water sources, returned. Therefore, reorientation can be and groundwater quality; (2) compensation interpreted as a review of the tendency of for the recovery of environmental damage view or thought. In this research, due to groundwater extraction and / or reorientation is interpreted as a review of the utilization, shall be subject to compensation views that underlie thinking in the costs for all types of groundwater uptake and establishment of an investment law based on for all levels of impact of groundwater corruption prevention in Indonesia.

\section{Literature Review}

Groundwater Tax

Tax are mandatory contributions to the state treasury owed by individuals or entities that are coercive based on the law, with no direct compensation and are used for state purposes for the greatest prosperity of the people (Mardiasmo, 2009; Wibowo \& Sandikapura, 2019). Thus, local tax is determined by local government through The Regional regulation of Garut Regency No. 1 of 2016 and The Law of Republic of Indonesia No. 28 of 2009 reveal that the tax income used for local development. There are several taxes collected by the local government, which consists of: (1) The provincial tax; and (2) The regional tax, involve groundwater tax. Based on the prior research the the local government should arrange the tax policy to increase local income (Anicic, et al., 2015). According to the Law of Republic of Indonesia No. 28 of 2009 the ground water tax determined as Regency / City tax. In the regulation this tax defined as the extraction and / or utilization of ground water by individuals or entities that solely use ground water for business activities. Besides that, the ground water tax in Garut Regency is stated in the Garut Regent's Regulation Number 14 of 2019 concerning Guidelines for Determination and Calculation of Groundwater Acquisition not have licenses or are illegal in the use of Value as the Basis for Imposing Ground ground water. Extension of a permit or to Water Tax, explaining that "Groundwater is obtain a permit for the utilization of ground uptake whether or not it has caused environmental damage; and (3) The allocation and management of groundwater is distinguished based on the subject of the user or group of groundwater users which are determined become 5 groups.

\section{Research Method}

The methods in this research is descriptive analysis. The type of data uses qualitative data that obtained from The Regional Revenue Office of Garut Regency. The data source used primary and secondary data relate with groundwater tax. The data collection technique is conducted with literature review, documentation, and interviews. The data analysis using the formula on the growth, contribution and potential. Besides that, in this research use SWOT analysis to identify internal and external factors that influence the achievement of organizational goals based on strengths, weakness, opportunity, and threatness. The location of research conducted in Regional Revenue Office at Otista Street No. 278 Garut.

\section{Discussion}

The main problem of ground water taxation in Garut Regency is that there are still many groundwater tax taxpayers who have not extended their permits or even do https://journals.telkomuniversity.ac.id/jaf 
water tax is the authority of the provincial office or the office of Energy and Mineral Resources, as a result Garut Regency does not have the authority to intervene in the licensing process. Garut Regency has 3 (three) subdistricts whose potential receiving groundwater taxes, namely Tarogong Kidul District, Tarogong Kaler District and Garut Kota District. During 2016-2019 period the average growth of the ground water tax reached $-13.65 \%$, which means that groundwater tax revenues have decreased. Except, in 2018 the realization of ground water tax revenues has grown, exceeding the target of Rp. 51,501,126. The percentage of negative tax growth can occur due to reduced groundwater taxpayers. Meanwhile, the contribution of groundwater tax to the Garut Regency regional tax revenue during the 2016-2019 period showed the highest contribution of ground water tax occurred in 2016 amounted to $1.37 \%$ and its contribution to regional tax declined over the last three years. During the period of 2017 - 2019 the percentage of ground water tax contributions has decreased. The contribution of ground water tax to the regional tax revenue in Garut Regency is still very small with an average of less than $1 \%$ or $0.83 \%$. Based on the obervation of the ground water taxpayer obervation in Garut Regency, currently there are 161 licensed taxpayers, and the permit period expires. Based on the data processing carried out, it shows the classification of tax payers for Garut Regency in 2019 the highest number of taxpayers was group 4 of 58 taxpayers, while the number of ground water tax receipts was obtained from group taxpayers 2. The amount of revenue from group 2 groundwater tax is $\mathrm{Rp} 256,311,578$ or $48.55 \%$ of the total ground water tax which reaches Rp. 527,976,991. The SWOT strategy is connecting internal and external elements so that four alternative strategies can be obtained to obtain maximum effort. Efforts that must be made to increase Underground Water tax revenues include

\section{Conclusion}

Based on the analysis of groundwater tax planning in Garut Regency, obtain conclusion The potential for ground water tax in Garut Regency is quite large, the number of registered groundwater taxpayers is only 160 taxpayers, but only 40 taxpayers still have licenses. Seen from the growth rate and contribution of the ground water tax over the past 5 years, the tendency has decreased, as a result of the reduced number of licensed taxpayers who can be subject to groundwater taxation. In addition, based on SWOT analysis drawn the conclusion that groundwater tax plans namely identify and map potential groundwater utilization, utilizing technology for measuring groundwater utilization, improving management strategies and services to taxpayers, maximizing the intensification of the ground water tax, regulate the groundwater utilization permits, increase the quantity and quality of tax officials through coaching and training, re-identification of potential groundwater taxpayers, the tax collection process by tax officials is more active, determination of the amount of ground water tax in accordance with applicable regulations.

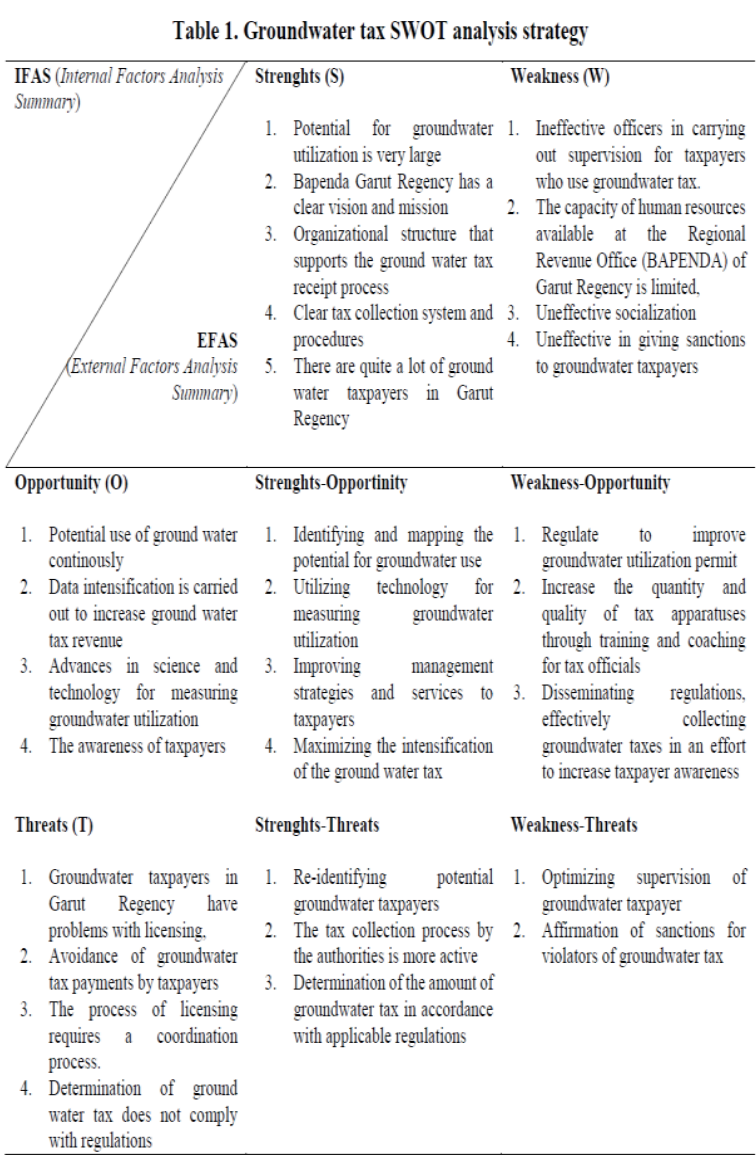




\section{References}

Anicic, J., Jelic, M. \& Durovic, J. M. 2015. Local

Tax Policy in the Function of Development of Municipalities. Social and Behavioral Sciences, Volume 221, pp. 262-269.

Davey, K. J. 1998. Pembiayaan Pemerintah Daerah Praktek-Praktek Internasional dan Relevansinya Bagi Dunia. Jakarta: UI Press.

De Paula, A. \& Scheinkman, J. A. 2010. Value Added Taxes, Chain Effects, and Informality. American Economic Journal, pp. 195-221.

Direktorat Jenderal Pajak RI, n.d. Salinan Peraturan Direktur Jenderal Pajak Nomor PER-35/PJ/2013. s.1.:s.n.

Direktorat Jenderal Pajak RI, n.d. Surat Edaran Direktorat Jenderal Pajak Nomor SE 06/PJ.9/2001 tentang Pelaksanaan Ekstensifikasi Wajib Pajak dan Intensifikasi Pajak. s.l.:s.n.

Fred, R. D. 2011. Strategic Management Concepts and Cases. 13 ed. America: Prentice Hall.

Hunger, J. D. \& Thomas, L. W. 2003. Manajemen Strategis. Yogyakarta: ANDI. Irianto, E. S. \& Jurdi, S. 2005. Politik Perpajakan: Membangun Demokrasi Negara. s.l.:UII Press.

Ismail, S. 2012. Manajemen Strategik. Jakarta: Erlangga.

Kesit, B. P. 2005. Pajak dan Retribusi Daerah. Yogyakarta: UII Press.

Koontz, H., O'Donnel, C. \& Weihrich, H. 1993. Manajemen. 8 ed. Jakarta: Erlangga.

Mardiasmo. 2002. Otonomi dan Manajemen Keuangan Daerah. Yogyakarta: Andi.

Mardiasmo. 2009. Akuntansi Sektor Publik. Yogyakarta : Andi.

Mardiasmo. 2011. Perpajakan Edisi Revisi 2011. Yogyakarta: Andi.

Pemerintah Kabupaten Garut. 2019. Peraturan https://journals.telkomuniversity.ac.id/jaf
Bupati No 14 Tahun 2019 Tentang Pedoman Penetapan dan Perhitungan Nilai Perolehan Air Tanah. Garut: Pemerintah Kabupaten Garut.

Pemerintah Provinsi Jawa Barat. 2017. Peraturan Gubernur Jawa Barat Nomor 50 Tahun 2017 Tentang Pedoman Penetapan Nilai Perolehan Air Tanah. Bandung: Pemerintah Provinsi Jawa Barat.

Raharjo, B. 2007. Keuangan dan Akuntansi untuk Manajer Non Keuangan. Yogyakarta: Graha Ilmu.

Republik Indonesia. 2009. Undang-Undang Nomor 28 Tahun 2009 tentang Pajak Daerah dan Retribusi Daerah. s.l.:s.n.

Republik Indonesia, n.d. Undang-Undang Nomor 23 tahun 2014 Tentang Pemerintahan Daerah. s.l.:s.n.

Republik Indonesia, n.d. Undang-Undang Nomor 34 Tahun 2000 tentang Perubahan atas Undang-Undang Republik Indonesia Nomor 18 tahun 1997 tentang Pajak dan Retribusi Daerah. s.1.:s.n.

S. 2013. Pajak Daerah dan Retribusi Daerah. Jakarta: Raja Grafindo Persada.

Sari, C. W. 2018. Kemarau, Pendapatan Pajak Air Permukaan Menurun. Bandung Raya, 12 September.

Suryadi, P. \& Dewi, P. 2014. Manajemen Strategik dan Pengambilan Keputusan Korporasi. Jakarta: PT. Bumi Aksara.

Waluyo. 2011. Perpajakan Indonesia Edisi 10 Buku 1. Jakarta: Salemba Empat.

Wheelen, T. L. \& Hunger, J. D. 2010. Strategic Management and Business Policy. 12 ed. America: Prentice Hall.

Wibowo, S. \& Sandikapura, T. 2019. Improving Data Security, Interoperability, and Veracity using Blockchain for One

Data Governance, Case Study of Local Tax Big Data. [Online] Available at: https://dea.uii.ac.id/user/lihat_publikasi/i proving-data-security-interoperability-and veracity-using-blockchain-for-one-data governance-case-[Accessed 18 July 2020]. 